\title{
JURIDICAL ANALYSIS ON THE LEGAL POWER OF COLLATERAL SEIZURE ON MATRIMONIAL JOINT ASSETS IN THE DECISION OF MANNA RELIGIOUS COURT NO. 54/PDT.G/2019/PA.MNA BASED ON ISLAMIC LAW
}

By:

Fauzi, Subanrio, Akhmad Muslih

\begin{abstract}
The objectives of the study were to find out and analyze: (1) the reasons of collateral seizure on matrimonial joint assets where it can guarantee the Plaintiff's rights and (2) The views of Islamic law on the collateral seizure of matrimonial joint assets in the decision of Manna Religious Court No.54/Pdt.g/2019/PA.Mna. This study was normative legal research. The reasons for the seizure of the collateral filed by the Plaintiff in the lawsuit case No.54/Pdt.G/2019/PA.Mna were: a) the reasons for collateral seizure on matrimonial joint assets were due to the Plaintiff's claim in the lawsuit concerning the assets under the Defendant's authority; b). Judge panel considered the rules based on Al-Qur'an surah An-Nisa verse 32, regulation in Marriage Law, and Compilation of Islamic Law that state the right of Matrimony Joint Assets belongs to both parties, and since the assets were under the Defendant's authority, a collateral seizure is considered necessary; c) the reasons of collateral seizure on matrimonial joint assets were also to provide legal certainty and equal rights to each party; d) to ensure the integrity of the assets, to get them to remain maintained and present; and e) the seizure was to avoid the right transfer of the asset to other parties and to prevent the assets from being misused or damaged. The legal power of collateral seizure of matrimonial joint assets in the decision of Manna Religious Court No.54/Pdt.g/2019/PA.Mna could give the Plaintiff's legal rights in writing, but when viewed from Islamic law it could not be able to achieve the objectives of Islamic law itself, namely the benefit and usefulness principles. This was due to the absence of sanctions and strong foundations for those who did not carry out the decision. The court only granted the seizure stamp and joint assets seizure but did not decide the execution over the joint assets, so the Plaintiff's rights could not be fully protected. Islamic law considered the collateral seizure on matrimonial joint assets in the decision of the Manna Religious Court No.54/Pdt.g/2019/PA.Mna as something that is not prohibited and mentioned in surah Al-Baqarah verse 188.
\end{abstract}

\section{Key Words : Legal Power of Collateral Seizure, Matrimonial Joint Assets, Religious} Court Judge's Decision, Islamic Law. 


\section{A. INTRODUCTION}

\section{Research Background}

Marriage is a sacred bond that unites two hearts and two families into one. Marriage has a purpose to have offspring, create a happy, prosperous, safe, peaceful, and full of love household ${ }^{1}$. Marriage according to Islam aims to create a sakinah, mawadah and warohmah family and to give birth to good offsprings. Therefore, Islam carefully deals with the problem of marriage to bring humankind to an honorable life in the highest position among other beings ${ }^{2}$. Marriage creates rights and obligations to the parties who do so. Legal marriage will have legal consequences for the relationship between husband and wife, property for marriage, and the relationship between parents and children $^{3}$.

The breakup of the marriage takes several forms depending on who intends to terminate the marriage. In this case, there are 4

1 Sirman Dahwal, Hukum Perkawinan Beda Agama Dalam Teori Dan Praktiknya Di Indonesia,Mandar Maju, Bandung, 2016, hlm. 87.

Ahmad Azhar Basyir, Hukum Perkawinan Islam, Penerbit UII Press, Yogyakarta, cet. II, 2007, hlm. 1

3 Mulyadi, Hukum Perkawinan Indonesia, Badan Penerbit Universitas Diponegoro Semarang, 2008, hlm. 41. (four) possibilities including:

1. Divorce by the will of Allah Almighty through the death of husband or wife. With that death, the marital relationship ended by itself;

2. Divorce by the will of the husband due to certain reason(s) and he states the will through the divorce sentence. The dissolution of marriage in this form is called talak;

3. Divorce by the will of the wife because she sees something that leads to the dissolution of the marriage, while the husband rejects it. The will to terminate the marriage is conveyed by the wife in this particular way and is accepted and ended with the divorce sentence by the husband. The dissolution of marriage in this form is called khulu;

4. Divorce by the will of the judge as a third party after seeing the presence of something on husband and/or wife which indicates that the marriage relationship can not be extended. The dissolution of marriage in this form is called fasakh.

Based on the description above, one of the forms of marriage termination is divorce. Islam does not forbid divorce in marriage but God hates divorce. A divorce between husband and wife is governed by Article 39 paragraph 
(1) of Law No. 16 of 2019 on Amendment of Law No. 1 of 1974 concerning Marriage. The law states that:

Divorce can only be carried out before a court hearing after the court concerned has tried and failed to reconcile the two parties.

Divorce between husband and wife is caused by several factors, ones of which are incompatibility and economic factors. The Manna Religious Court, the court with authority to settle and terminate marital relations through a lawsuit or husband/wife request, recorded the number of divorce cases terminated from December - May 2019 was up to 124 cases $^{4}$. The high number of divorces between husband and wife indicated the conflict in social relations between husband and wife who had been divorced would increase, especially the problems related to children and joint assets. The assets from the time of marriage is often referred as matrimonial joint assets. Matrimonial joint assets according to Article 35 paragraph (1) of Law No. 16 of 2019 on Amendment to Law No. 1 of 1974 concerning manna.go.id/statistik_perkara
Marriage are:

Property acquired during the marriage becomes shared property.

Based on this article, the explanation of what is meant by joint assets are assets obtained during the marriage. The distribution of joint assets occurs if the husband and wife have a legal divorce before the court and the distribution mechanism is clearly regulated in Article 37 of Law No. 1 of 1974 which states that:

If marriages break up due to divorce, the distribution of joint assets is regulated according to their respective laws.

Based on the contents of Article 37 of Law No. 16 of 2019 on Amendment to Law No. 1 of 1974 concerning Marriage, it states that the arrangement of joint assets and distribution is according to their respective laws. Each law here is a law that specifically regulates joint assets. If the husband and wife are Moslem, the distribution of joint assets will be according to the provisions of Islamic law contained in the compilation of Islamic law and the results contained in the court decision. The panel of judges in deciding the case of joint assets sometimes includes the existence of 
the seizure of collateral for objects which become joint assets, this is done as a form of security for the property in dispute that is being controlled by one of the parties. As one example of the decisions where judges ordering the seizure of collateral is the decision of Manna Religious Court No. 54/PDT.G/2019/PA.Mna.

Based on the Decision, one of the contents of the decision was the existence of collateral seizure in the interim decision that must be implemented. Placing the seizure stamp was carried out with consideration to identify the object as the object of dispute and when it was under the defendant's authority, the object could not be transferred or sold to another party. Placing the seizure stamp was carried out before the verdict was read. After being laid down, the decision of the judge panel ordered the seizure to the object of dispute with collateral seizure stamp and proven to still exist, and both parties must obey the decision. However, in reality, after the decision had final legal force, one of the parties, the defendant, was not compliant with the decision.

The interim decision on case No. 54/PDT.G/2019/PA.Mna was carried out for several reasons:

1. Most of the joint assets belong to both the plaintiff and defendant were under the plaintiff's control.

2. The plaintiff suspected that assets had been transferred through the sale and purchase agreement to other parties.

3. As long as the property held by the defendant, the plaintiff did not get income from the joint assets which were used as the defendant's business object.

Based on the description above, the authors were interested to know and analyze more deeply, and the authors believed that this case had its uniqueness in the implementation of the execution. The authors thought that the seizure stamp could not prevent the joint assets to be transferred. Besides, the authors also wanted to review the case based on the Islamic law and compiled it into a journal entitled "Islamic law on the collateral seizure of matrimonial joint assets contained in the decision of Manna Religious Court No. 54/PDT.G/2019/PA.Mna "

\section{Research Identification}

1. Why the collateral seizure was filed by the Plaintiff in 
lawsuit

54/Pdt.g/2019/PA.Mna.?

2. How is the legal power of collateral seizure in the decision of Manna Religious Court No. 54/PDT.G/2019/PA.Mna to keep Plaintiff's rights?

3. To what extent Islamic Law views the collateral seizure of joint assets in the decision of Manna Religious Court No.

54/PDT.G/2019/PA.Mna to keep Plaintiff's rights?

\section{B. RESEARCH METHODOLOGY}

The method used in this study was qualitative research. Qualitative research is research that uses a holistic approach that requires a variety of information to be analyzed so that certain aspects of human attitude can be understood. $^{5}$

\section{RESULTS AND DISCUSSION}

\section{The reason of collateral seizure} filed by the plaintiff in Lawsuit No 54/Pdt.g/2019/PA.Mna

In addition to the suitability of the reasons for collateral seizure of

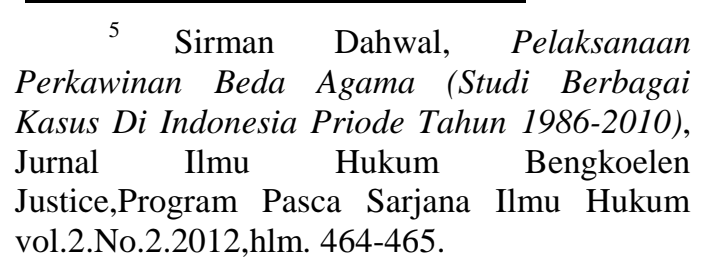

matrimonial joint assets in the decision of Manna Religious Court No. 54/PDT.G/2019/PA.Mna. with the theories of authority, decision, and justice, the seizure was done according to the theory of law enforcement. Law enforcement is an effort to bring the ideas of justice, legal certainty, and social benefits into reality. Therefore it is essentially a process of embodying ideas. It is the process of carrying out efforts or the actual functioning of legal norms as guidelines for people or legal relations in the life of society and the state. This is all reflected in the decision of the judges' consideration.

Based on the legal considerations of judges panel contained in the decision of the Manna Religious Court judge No. 54/Pdt.G/2019/PA.Mna it was shown that the reasons for collateral seizure filed by the Plaintiff were:

1. The collateral seizure of joint assets in the decision of Manna Religious Court No.54/Pdt.G/2019/PA.Mna was due to the Plaintiff's request contained in the lawsuit because the assets were under the Defendant's control; 
2. The judges' consideration was based on the rules contained in Al-Qur'an surah Annisa verse 32 and the rules in Marriage Law and compilation of Islamic Law. They state that matrimonial joints assets were divided into two parties and because the property was under the Defendant's authority, the collateral seizure was necessary;

3. The collateral seizure of joint assets in the decision of the Manna Religious Court No. 54 / Pdt.G / 2019 / PA.Mna also provided legal certainty and equal rights to each party as stipulated in the legislation and legal theory as the reference for the judge panel in giving a decision;

4. To guarantee the integrity of the objects in dispute to keep them maintained and existed so that when the decision was executed, the defendant's assets were available to fulfill the implementation of the decision and at the same time to ensure the plaintiff's rights and interests fulfilled;

5. Collateral seizure prevented the objects from being transferred to another party, misused or damaged.

2. Legal Power of Collateral Seizure in Decision of Manna Religious Court No.54/Pdt.G/2019/PA.Mna to Guarantee the Plaintiff's Rights

Based on the two benefits to be addressed in Islamic law, those two benefits are only a concept of collateral seizure of matrimonial joint assets contained in the decision of Manna Religious Court No. 54/Pdt.G/2019/PA.Mna, and they could not be realized and implemented well in reality. This was because the legal power of collateral seizure of joint assets in the decision based on the Islamic law had neither permanent legal power nor binding sanctions.

The legal power of collateral seizure of joint assets in the decision of Manna Religious Court No. 54/Pdt.G/2019/PA.Mna based on Islamic law had neither permanent legal power nor binding legal power. This could be seen from the judge panel's considerations where there was no sanction if the defendant did not surrender the seized objects. In addition, the decision of granted the placement of seizure stamp and the seizure of the joint assets but did not decide on the 
execution of the joint assets. From the analysis, the decision was in line with the law enforcement theory of Dellyana, Shant, where law enforcement is an attempt to realize legal ideas and concepts that people expect to become reality. Law enforcement is a process that involves many things, so the collateral seizure of joint assets in the decision of Manna Religious Court No. 54/Pdt.G/2019/PA.Mna which had no binding legal force could not be an instrument that carries out law enforcement well.

Based on the explanation above, it could be concluded that the legal power of collateral seizure of joint assets in the decision of Manna Religious Court No.54/Pdt.G/2019/PA.Mna could guarantee the Plaintiff's rights in writing and was in accordance with the law enforcement theory and legal philosophy theory in which the procedure is passed, then it is considered to be a solution in solving existing legal problems. However, when viewed from Islamic law it had not been able to achieve the objectives of Islamic law, namely the benefits and usefulness of the matter due to the absence of strong sanctions and foundations for those who did not carry out the collateral seizure of the joint assets. Besides, the decision of Manna Religious Court No.54/Pdt.G/2019/PA.Mna granted the placement of seizure stamp and the seizure of the joint assets but did not decide on the execution of the joint assets so that the Plaintiff's rights could not be fully protected.

\section{Islamic Law on Collateral Seizure in Decision of Manna Religious Court No.54/Pdt.G/2019/PA.Mna}

Islamic law considered the collateral seizure of joint assets in the decision of Manna Religious Court No.54/Pdt.G/2019/PA.Mna as something that is not prohibited and is an act that can provide a benefit for both parties. This was also in accordance with the decision theory according to Jeremy Bentham which states that the purpose of the law is that it can guarantee happiness to individuals and then to the group of people. Bentham's utility principle states "the greatest happiness of the greatest number".

Islamic law considered the collateral seizure of joint assets in the decision of Manna Religious Court No.54/Pdt.G/2019/PA.Mna as something that is not prohibited and is mentioned in verse 188 
of surah Al-Baqarah. The seizure also had a purpose that in line with Islamic law, namely to maintain the welfare of mafsadat both in this world and the hereafter. In addition, the collateral seizure of joint assets in the decision of Manna Religious Court No.54/Pdt.G/2019/PA.Mna was one of maslahah mursalah which is maslahah alhajjiyat needed to make ends meet.

\section{CLOSING}

\section{Conclussion}

1. The reasons for collateral seizure in decision of Manna Religious

Court

No.54/Pdt.G/2019/PA.Mna filed by the Plaintiff were:

a. The collateral seizure of joint assets in the decision of Manna Religious Court No.54/Pdt.G/2019/PA.Mn a was due to the Plaintiff's request contained in the lawsuit because the assets were under the Defendant's control;

b. The judges' consideration was based on the rules contained in Al-Qur'an surah Annisa verse 32 and the rules in Marriage Law and compilation of Islamic Law. They state that matrimonial joints assets were divided into two parties and because the property was under the Defendant's authority, the collateral seizure was necessary;

c. The collateral seizure of joint assets in the decision of the Manna Religious Court judge No.54/ Pdt.G/2019/PA.Mna also provided legal certainty and equal rights to each party as stipulated in the legislation and legal theory as the reference for the judge panel in giving a decision;

d. To guarantee the integrity of the objects in dispute to keep them maintained and existed so that when the decision was executed, the defendant's assets were available to fulfill the implementation of the decision and at the same time to ensure the plaintiff's rights and interests fulfilled;

e. Collateral seizure prevented the objects from being transferred to 
another party, misused or damaged.

2. The legal power of collateral seizure of joint assets in the decision of Manna Religious Court

No.54/Pdt.G/2019/PA.Mna

could guarantee the Plaintiff's rights in writing and was in accordance with the law enforcement theory and legal philosophy theory in which the procedure is passed, then it is considered to be a solution in solving existing legal problems. However, when viewed from Islamic law it had not been able to achieve the objectives of Islamic law, namely the benefits and usefulness of the matter due to the absence of strong sanctions and foundations for those who did not carry out the collateral seizure of the joint assets. Besides, the decision of Manna Religious Court No.54/Pdt.G/2019/PA.Mna granted the placement of seizure stamp and the seizure of the joint assets but did not decide on the execution of the joint assets so that the Plaintiff's rights could not be fully protected.
3. Islamic law considered the collateral seizure of joint assets in the decision of Manna Religious Court No.54/Pdt.G/2019/PA.Mna as something that is not prohibited and is mentioned in verse 188 of surah Al-Baqarah. The seizure also had a purpose that in line with Islamic law, namely to maintain the welfare of mafsadat both in this world and the hereafter. In addition, the collateral seizure of joint assets in the decision of Manna Religious Court No.54/Pdt.G/2019/PA.Mna was one of maslahah mursalah which is maslahah alhajjiyat needed to make ends meet.

\section{Suggestions}

It is suggested that the decision includes the sanctions against those who do not carry out the decision on collateral seizure of matrimonial joint assets, and in the future, the government should make clear and firm regulations while the Islamic leaders make fatwa related to joint assets and the implementation of joint assets distribution so that they have binding legal regulations. 


\section{REFERENCES}

Abdul Manan, Aneka Masalah Hukum Acara Perdata Islam di Indonesia, Kencana Prenada Media,Jakarta,2006

Ahmad Azhar Basyir, Hukum Perkawinan Islam, Penerbit UII Press, Yogyakarta, cet. II, 2007,

A. Sonny Keraf, Etika Bisnis Tuntutan Dan Relevenansinya, Kanisius, Yogyakarta, 2005,

Badriyah Harun, Tata Cara Menghadapi Gugatan, Pustaka

Yustisia,Yogyakarta, 2009

Harahap M. Yahya, Hukum Acara Perdata Tentang Gugatan, Persidangan, Penyitaan, Pembuktian, dan Putusan Pengadilan, Sinar Grafika, Jakarta: 2006

Izaac S. Leihitu dan Fatimah Achmad, Inti dari Hukum Acara Perdata, Ghalia Indonesia, Jakarta, 1985,

Muhammad Syaifuddin dan Sri Turatmiyah dan Annalisa Yahanan, Hukum Perceraian. Sinar Grafika, Jakarta,2013,

Mulyadi, Hukum Perkawinan Indonesia, Badan Penerbit Universitas Diponegoro Semarang, 2008,

Rosnidar Sembiring, Hukum Keluarga Harta-Harta Benda dalam Perkawinan, PT. RajaGrafindo Persada, Jakarta,2016

Satria Effendi dan M. Zein, Problematika Hukum Keluarga Islam Kontemporer Analisis Yurisprudensi dengan Pendekatan Ushuliyah,Kencana, Jakarta,2004
Sayuti Thalib, Hukum Kekeluargaan Indonesia: Berlaku Bagi Umat Islam,: Penerbit Universitas Indoenisa (UIPress), Jakarta ,2000

Sayyid Sabiq, Fikih Sunnah 8, Alih Bahasa:Drs. Mohammad Thalib, PT. Alma'arif, Bandung, 1997

Sirman Dahwal, Hukum Perkawinan Beda Agama Dalam Teori Dan Praktiknya Di Indonesia,Mandar Maju, Bandung, 2016, Beda Agama (Studi Berbagai Kasus Di Indonesia Priode Tahun 19862010), Jurnal Ilmu Hukum Bengkoelen Justice,Program Pasca Sarjana Ilmu Hukum vol.2.No.2.2012,

Wildan Suyuthi, Sita dan Eksekusi: Praktek Kejurusitaan Pengadilan, PT Tatanusa, Jakarta, 2004, hlm. 20 